\title{
Beware of Historians Bearing False Analogies
}

\section{By: Walter W. Rostow}

Date: March 1988

Abstract:

A response to the book The Rise and Fall of the Great Powers by Paul Kennedy (1987).

Keywords: foreign affairs

IC2 Institute Working Paper WP-1988-03-02

国国 The University of Texas at Austin

$\mathrm{IC}^{2}$ Institute

Office of the Vice President for Research

(C) IC' Institute, The University of Texas at Austin

http://ic2.utexas.edu 
BEWARE OF HISTORIANS

BEARING FALSE ANALOGIES

by

Walt Rostow

Working Paper \#88-03-2 


\section{Beware of Historians Bearing False Analogtes}

Paul Kennedy, The Rise and Fall of Great Powers, New York: Random House, 1987. Pp.xxv +678. \$24.95.

Paul Kennedy, an Englishman translated to New Haven, succeeds to a proud tradition reaching back more a half century, including among other dis-

' tinguished scholars from across the Atlantic, Nicholas Spykman and Arnold Wolfers, who introduced Yale students of the 1930 s to the harsh realities of geopolitics, war, and diplomacy.

Kennedy has written a rather massive book around a grand theme: The relation between the rise and fall of major powers over the past five centuries to shifts in their relative economic strength and technological virtuousity. It is, at once, a work of historical analysis in which the author seeks to discern recurrent patterns on which he can base defensible generalizations; an analysis of the recent past and projection of present trends as he perceives them; and a policy prescription, notably for the United States. Understandably, it is the latter strand that is receiving much attention in the media; but before examining Kennedy's advice to Americans it is worth surveying briefly the other two dimensions of his work to which his final admonition is related. II.

[ - Kennedy begins with a brief survey of the world scene round about 1500. It includes quick portraits of Ming China, the Muslim world including Mogul India, pre-Tokugawa and Tokugawa Japan, pre-Petrine Russia, and Europe before the rise of the modern nation states.

He then brings on stage his succession of melodramas of rise and fall: the Habsburgs (1519-1659); the Anglo-French struggle in the wake of brief Dutch primacy (1660-1815); Post-Napoleonic British primacy (1815-1885) and its 


\section{Foretgn Affairs}

$-2-$

erosion (1885-1918); the rise of the Untted States and the U.S.S.R. at the expense of the middle powers [Britain, France, Germany, and Japan] (1919-1942); the bipolar world and the beginnings of its erosion (1943-1980).*

All this takes up approximately seventy percent of the book. It involves the mobilization of a large volume of evidence, much of it not directly related to his central theme. Its style evokes something of text books of the past -say, the second half of H.A.L. Fisher's A History of Europe -- updated, with somewhat more economic history, but wi thout Fisher's turn of phrase.

Sensing the diffuse character of his exposition, Kennedy provides a terse ten page Introduction. There he confronts two of the major unresolved analytic problems that run through his study and fails to confront a third. First, he asks: How much generalization is justified by this tale of battle and blood and wasted resources? He distinguishes his position from that of political scientists who seek general rules about world systems, recurrent patterns of wars, power-distance ratios, etc. The evidence, he finds, is too conflicting for any tidy laws of history. He limits himself to three unsurprising propositions (pp. $x x i j-x x i i j)$ :

-- There is a causal link between economic strength and the power position of states in the international system.

-- In the long run, the rise and fall of states is related to their

* With justification, $\longleftarrow$ Kennedy takes 1942, with allied victories in the Coral Sea, Midway, North Africa, and before Stalingrad, as the turning point in the Second World War after which the U.S. and U.S.S.R. progressively emerge as dominant. In my view the erosion of bipolarity and the diffusion of power away from Washington and Moscow began as early as 1948 when the U.S. Congress passed the Marshall Plan legislation and Tito successfully broke with Stalin. 
relative economic position in the world economy.

-- There is a time lag between the trajectory of a nation's relative economic strength and its relative military-territorial influence.

Second, Kennedy, historian that he is, draws back a bit even from this degree of "crude economic determinism." He lists ( $p . x x i v$ ) other factors that have affected relative national success and failure in the arena of power: geography, military organization, national morale, the alliance system among others. These are, however, not pursued systematically in the analyses that follow.

Third, is his missing insight

he fails to distinguish sharply those states which pursued policies of regional hegemony from those content with a balance of power policy; that is, a policy which aimed to prevent the hegemony of any other power in their region. In the post-1500 era marked, above all, by the triumph of nationalism, it has made quite a difference whether a power set out to suppress the nationalism of others or to help mobilize the nationalism of others in resisting that suppression. It is a distinction worth making.

Kennedy does quite well with the great pursuers of hegemony. Thus, the Habsburgs, inheritors of a vision of a Holy Roman empire, caught up in a commitment to continental hegemony from which they could never escape, enflamed by the flow of bullion from their American colonies, continuously at war, while their opponents, resisting attempted domination, enjoyed periods of respite, peace, and recovery. We see Napoleon, similarly driven but by a different set of forces, impelled literally to install members of his family in his conquered domains, generating nationalist opposition the British systematically exploited 
to bring him down. Thus also the defeat of the Kaiser, Hitler, and the Japanese militarists by the concerted efforts of those not prepared to accept their hegemony. Kennedy might well have quoted the Hamletian Chief of the German General Staff, in 1914, General Helmuth von Moltke, trapped by the Schlleffen Plan he inherited, who foreshadowed his country's fate (and 'shocked assistants) with the old German peasants' adage: "Many dogs are the hare's death."

The central problem of Kennedy's analys is and, later, prescription for the U.S., centers on his treatment of Great Britain in relation to the other cases of rise and decline. There is a passage in Kennedy's book which, I felt, might lead him to get it right. It asks a good question: "Britain as Hegemon?" (pp. 151-158). It evokes Britain at the height of its power, with Europe in reasonable diplomatic equilibrium aided notably by Bismark's restraint. It was an equilibrium about to break down; but it represented a technique for exercising power in a multi-polar arena quite different from Britain's predecessors or attempted hegemonic successors in Europe. A balance of power state may not be 1iked; but it is almost certain to find allies when it confronts a power intent on regional hegemony.

The British decline thus differs from the others. Its relative role in fending off hegemony in Europe by a succession of powers was, indeed, reduced by the progressive industrialization of other states. But its relative decline as a European and Atlantic power is not the result of pursuing a hegemonic dream in Europe.

Britain did exercise hegemonic powers in the empire; and despite the recognition after 1783 that such powers would progressively wane as nationalism 
gathered strength, the end of the imperial dream was psychologically and politically traumatic, but not economically costly in any direct sense. That trauma postponed Britain's recognition that its destiny lay primarlly with the European continent; and the initial postponement gave de Gaulle the occasion for further delay. The problem that had to be overcome was captured in Dean Acheson's namely, that somewhat cruel analysis and challenge late in 1962 $\Lambda^{\prime}$ Great Britain had lost an empire but. $\rightarrow$ not yet found a role.

The most obvious generalization from Kennedy's saga is political rather than economic: the pursuit of hegemony strengthens nationalist resistance, expansionist renders the . effort increasingly costly, and out of its own dynamics, may drive a state to extend its exertions $\longrightarrow$ to a point where failure is inevitable as it reaches beyond its relative economic capacity.

As for the economics of the process, a state pursuing a balance of power policy may find its relative status shifting as the tricks of industrialization spread, but it is not destined to repeat the fate of Habsburg Spain, Napoleonic France, imperial and Hitlerite Germany, and Japanese militarism.

In short, Kennedy's generalizations from the historical record down to 1942 suffer from a confusion of the British with the other cases, and a confusion of two quite different links between economic resources and power in the world arena: the progressive economic strains imposed by the pursuit of hegemonic dreams in the face of affronted nationalism; and the progressive dilution of relative economic power as the British demonstration of take-off, starting in the 1780s, is followed for two centuries by a sequence of take-offs in continental Europe, North America, Latin America, Asia, and the Middle East (see chart). 
FOUR GRADUATING CLASSES INTO TAKE-OFF:

STAGES OF ECONOMIC GROWTH, TWENTY COUNTRIES

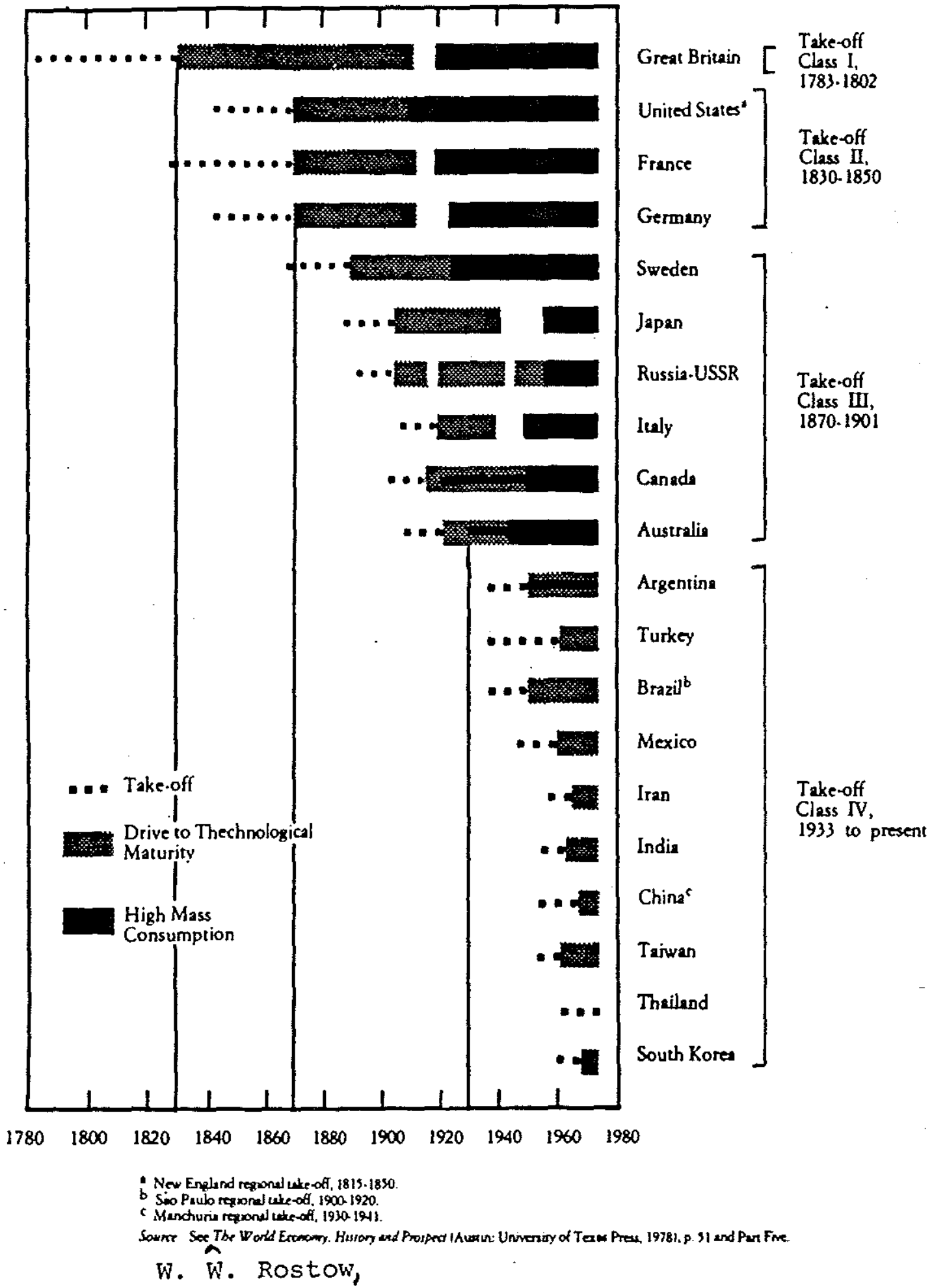


This distinction becomes central when Kennedy moves beyond 1942 in Chapter 7 ("Stability and Change in a Bipolar World, 1943-1980"). He claims his stylized portrait of the past forty-five years is based not on a priori-..theories but, simply, the "historical record." In fact, all historical

' analyses are based on a theory, explicit or implicit. The form Kennedy's theory assumes is a double analogy: he treats the post-1945 rise in U.S. power on analogy with other hegemonic empires of the past; its decline on analogy with his interpretation of the decline of Britain. Neither analogy, in my view, is particularly helpful.

Now, his stylized portrait. From 1943, he argues, the United States and the Soviet Union interpreted the world in bipolar power and ideological terms and acted in those terms. "Manichaen" (p. $x x$ ) is his code word as he applies rather crudely Alexis de Tocqueville's famous prediction about the destiny of the United States and Russia (pp. 343 and 365); although, presumably to perserve symmetry, he leaves out: "The principal instrument of the former is freedom; of the latter servitude." The two nations are presented as having equally fallen prey to "globalist" thinking. Henry Luce (p. 360) is quoted as the authoritative spokesman of American policy not Truman, Marsha11, Acheson, or clayton. An unnamed "American official" is evoked from a secondary source to explain: "It is now our turn to bat in Asia" in succession to British and Dutch imperialists (p. 361). American post-war economic policy is presented as an effort to exploit free trade and laissez-faire at a time of European weakness to consolidate American post-war economic primacy. This is the not unfamiliar litany of some on both sides of the Atlantic since the end of the Second World War. 
A full response to this caricature is not appropriate here. But it is worth recalling that in 1945-1946 the United States unilaterally dismantled its armed forces and gave every evidence in its political life of validating Frankl in Roosevelt's opening statement at Yalta that American forces could not be kept in Germany for more than two years. The Truman Doctrine and the Marshall - Plan were a belated response to a real and present danger to the balance of power -- an assessment fully shared by responsible officials on both sides of the Atlantic, notably after George Marshall's meeting with Stalin in April 1947. Similarly, it was the shock of the North Korean attack on South Korea which led to the creation of SHAPE within the hitherto rather empty structure of NATO.

The political instinct of the United States in 1945-1946 was to come home from the world as much as possible and rely to the maximum on its membership in the United Nations to keep the peace. In the actions taken in Europe the United States was not engaged in a mortal, obsessive, bi-polar duel for world power with the U.S.S.R. It was acting in continuity with its policy since 1917; namely, that it would move at times of acute crisis to redress the balance of power in Europe when that balance was palpably threatened. And it acted in a particular way. In 1945-1946 the following issue was debated in the U.S. Government: Should the U.S. support the unity of Europe at the certain cost of creating a great economic competitor, gambling that we would have a strong partner in holding the balance of power; or, should the U.S. maximize its short run power by exploiting its bilateral leverage over individual European countries? Well before the Marshall Plan offer, the U.S. government had decided on the former course. It has remained American policy in Europe for more than forty years. Washington was the steady friend of Jean Monnet -- his plans and dreams 
for a strong Europe -- not exactly the posture one would expect from a power caught up in a hegemonic seizure.

In Asia, too, if one examines what the United States did as opposed to the rhetorical sound track, it is clear that the nation acted quite consistently since the late nineteenth century in terms of the balance of power. The enunciation of the Open Door Policy had a curious history, as most events in public policy do; but it did, in fact, foreshadow U.S. policy towards China in the face of the rise of Japanese power in Asia. The balance of power was at the core of the American stance at Portsmouth after the Russo-Japanese War and in 1921-1922 during the negotiation of the Washington Naval Treaties, demerged with velt's drawing the line on Japan's expansion in 1941 -. with the cutting off of $0 i 1$ and scrap exports and the sequestering of Japanese assets in the U.S. -when Japan's forces moved from northern to southern Indo-China threatening freedom of transit in the critical South China. Sea. And so into the more than forty years since the end of the Second World War: the defense of South Korea, the Japanese Security Treaty, the Southeast Asia Treaty, the defense for twenty critical years of South Vietnam, Laos, and Cambodia, and the reaffirmation of the Southeast Asia Treaty as it applies to Thailand by Presidents Carter and Reagan despite the tragic outcome of the engagement in Vietnam. There is great continuity in this story.

The pursuit of a balance of power policy in Asia has not always been easy or cheap. In the face of Nationalist post-war weakness the U.S. government had to decide either to move into China with great force or to accept the take-over of China by a Communist government. The much criticized White Paper of 1949 made the case for the latter course. But the U.S, and its allies then contained 
expansionist impulse;

Mao's $\wedge$ helped build a vital Asia of strong nattonalist governments; and, as the U.S. government hoped forty years ago, $\longleftrightarrow$ a different China emerged out of its own dynamics having freed itself from the inherently un-natural alliance with Russia. The United States took heavy casualities -as did others -- in Korea and Southeast Asia -. with success in one case and ' debacle in the other. The Soviet navy is now in Cam Ranh Bay, the Soviet airforce in the Danang air field complex opposite Subic Bay and Clark Field. What is remarkable, however, is that despite the enflamed passions and rhetoric of the 1960s and 1970s over Vietnam, a balance of power policy is still alive in Southeast Asia, with widespread support in the region, including the support of China. And Thailand -- always the critical area -- remains inciependent and gathers strength.

Just as Kennedy does not capture the balance of power roots of American policy, he fails to deal clearly with the U.S. nuclear role. The conduct of a balance of power in Europe and Asia was, of course, complicated and rendered more expensive for the United States by $i t s$ role as nuclear guarantor for its allies and others opposing Soviet hegemony in both regions. No other nation

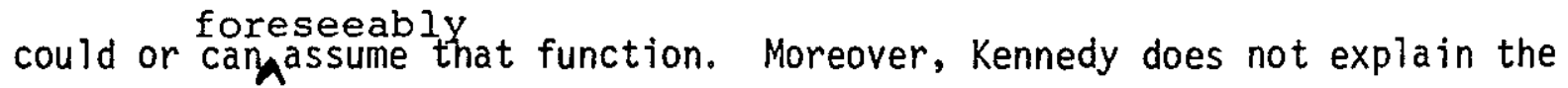
linkage of that posture to the possibilities of limiting or, at least, slowing down the process of nuclear proliferation. The U.S. government has stood against further nuclear proliferation for good and sufficient reasons as have many other governments. And for most countries, an American nuclear guarantee, backed by a conventional force presence on the gound or in the neighborhood, provides more security than a relatively small national nuclear capability. But as the 
"Supreme National Interest" clause in the Non-Proliferation Treaty makes clear, the containment of proliferation is, in good part, a matter of American reliability as an explicit or implicit ally.

As for the future, I have argued for at least thirty years -- most recently in Foreign Affairs. ("On Ending the Cold War," Spring 1987) -- that the global ageada in the several generations ahead will be dominated by the task of accommodating peacefully the rise of new industrial powers to full technological maturity. This is quite similar to Kennedy's perspective, although I would extend his list to include India, Brazil, and other countries in this category (see chart). Except for China, they get rather short shrift in his analysis.

Now Kennedy's prescription: The U.S. should shift resources from "security" to "investment" (pp. xxiij and 540), sacrificing short run military security to longer run economic security. It is here his analogy shifts from Russia and its predecessor hegemonic powers to his view of post-1945 Britain.

There are four observations to be made about this piece of advice.

First, of course;U.S. military outlays should be the minimum compatible with the protection of American vital interests. As a proportion of GNP, mijitary expenditures have declined from $13.2 \%$ at the peak of the Korean War; to $8.9 \%$ at the peak of hostilities in Southeast Asia (1967); to $6.5 \%$ in the fourth quarter of 1987. This trend decline is no cause for complacency; but it is often forgotten in the rhetoric of spiralling arms races.

Kennedy is quite aware of the trend but argues it does not take into account the relative rise in the economic power of other countries. His view would only be valid if the United States was seeking hegemony over those countries. In 
fact, the relative rise in economic power has mainly occurred in countries allied to the United States or where important common balance of power interests exist (e.g., India and China).

Second, the prospect is that the U.S. proportionate burden may decline further in the future as the result of (i) the 'relative economic rise of some U.S. allies; (ii) arms control agreements and other arrangements which reduce military burdens for both the U.S. and the U.S.S.R. The image that emerges from Kennedy's rhetoric and analysis -- of an America in the grip of compulsions to a linear expansion in its military outlays until it self-destructs -- is justified neither by past trends nor by reasonable hopes for the future.

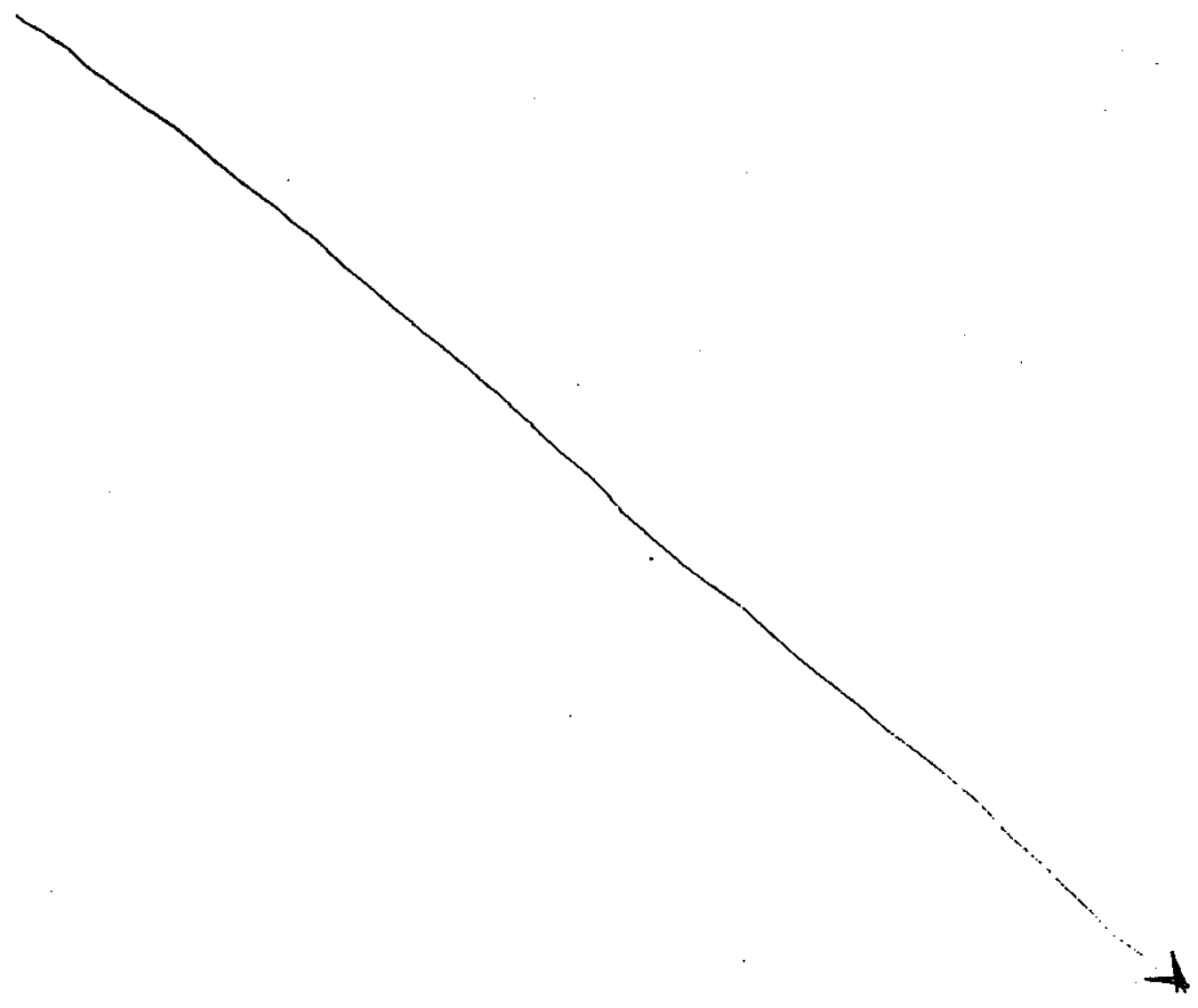


Third, desirable as it is, a relative reduction in military outlays does not automatically translate into a higher growth rate nor is a relatively high rate of growth incompatible with a relatively high rate of military expenditures.

' For example, the burden of U.K. military expenditures declined in the years down to 1978, while the economy continued to deteriorate. Something of the same could be said of the American economy in the 1970s as military expenditures declined to a trough of just under $5 \%$ of GNP in 1979. On the other hand, with a proportionate military outlay higher than the U.S., Taiwan, with $20 \%$ of U.S. GNP per capita, enjoys a much higher rate of growth. The situation of South Korea is similar. The capacity to reconcile a high rate of growth with a nation's security requirements is a much more complex affair than Kennedy allows.

Fourth, as I have argued elsewhere and at length, the challenge confronting the United States as it faces a protracted phase of increasing competition from the Fourth Graduating (liass chart) than Kennedy suggests: for example, improvement in the quality of the American educational system; increased co-operation between business and labor as well as 
bipartisan approaches to balancing the federal budget; intensified ties between military the universities and the private sector. Incidentally, despite a high $A_{\text {claim }}$ on U.S. R\&D resources, the U.S. seems to be maintaining its position reasonably well in the generation of new technologies. The critical dimension of competition lies in the pace at which entrepreneurs actually bring to bear the 'new technologies in production, a process not closely related to the military budget.

V

My conclusions about this book are, then, the following:

-- The author's failure to distinguish a balance of power from a hegemonic policy is a fundamental flaw in his analysis and prescription.

-- His familiar but still curious view of American diplomatic history conceals the fact that, stripped of rhetoric, the United States has pursued since its alliance with France during the Revolution a balance of power policy when ithe chips were down.

-- The pursuit of a balance of power policy has permitted the U.S. to avoid the vicious circle which engulfed all true hegemonic powers over the past five centuries; and, I would add, nuclear weapons and a certain historically rooted caution, has thus far saved the Soviet Union from that fate, although its society has been greatly strained by its hegemonic efforts.

-- For a balance of power country a satisfactory defense and a vital economy are not incompatible if, in David Hume's phrase, they remain "industrious" at home and conduct a "civilized" alliance policy abroad.

VI

A final word. Kennedy closes with a passage in which he tries to define 
the narrow margin open to statesmen (and their societies) in dealing with historical forces they can "neither create nor direct" -- a parable drawn from Bismarck, in a Hegelian mood, who once set the limit of the possible as steering "with more or less skill and experience" on "the stream of time."

Kennedy is, I suspect, somewhat more of a central European pessimist '(a)though born in Wallsend-on-Tyne) than the majority of Americans. As I went through the endless tables of relative economic power that characterize the text -- some incorporating my own calculations -- I thought from time to time he was taking these trends a bit too seriously. I felt that even more while working on this review, strongly after reading, the lead chapter in his Strategy and Diplomacy 18701945. (1983) entitled "The Tradition of Appeasement in British Foreign Policy, 1865-1939." It argues that Britain followed wisely a policy of appeasement -- of adjustment to the inevitable rise of other powers -- as it felt its primacy waning in the latter part of the nineteenth and twentieth centuries; that Neville Chamberlain was on the right track with Germany but for Hitler's actions which "discredited" appeasement and gave leverage to the "unholy alliance" of Left and Right which came to oppose Chamberlain.

In fact, there was more to British policy over the whole period Kennedy analyzes than passive adjustment to economic and military power trends; for example, the alliance with France after 1900 and the beginning of a sense in British policy that an American alliance might in time be necessary to redress the balance of power in the old world.

But my most fundamental disagreement with Kennedy is his tendency to regard history as linear. For example he clearly believes that societies can not regenerate. He regards calls for regeneration as the province of right 
wing patriotic politicians trying fruitlessiy to swim against the tides of history (pp. xxiii and 529-530).

I prefer the proposition in my youthful British Economy of the Nineteenth Century (1948); "History seems to be tolerant of the individual if he avoids the larger illusions of grandeur;" and even more, I prefer Churchill to Bis"marck ("... The course of history ... is always being altered by something or other."). Without a conviction that man has a somewhat larger control over his destiny than Bismarck and Kennedy suggest the British defeat of Napoleon and its remarkable World War II performance would have been impossible as would the quite unpredicted post-war regeneration of Western Europe and Japan, and a great many other heartening historical events. Indeed, while the media follow the presidential primaries in compulsive detail, the process of rehabilitation described in the January 29 th issue of Fortune proceeds vigorously in a fit of public absentmindedness: "Call the eighties the decade of restructuring. On to the scene rode the now familiar horseman of the corporate apocalypse -global competition, deregulation, accelerating technological change, and the threat of takeover." The fact is that the United States is much further along with restructuring than Mr. Gorbachev with perestroika; although both countries still have considerable distance to go.

There is a special reason that Americans should lean towards the Churchillian view that the margin of control over our destiny is, to a degree, more generous in 1961 than Kennedy allows. It was captured,at a difficult moment in the wake of the Bay of Pigs debacle. Presidenthrennedy said: 'The British could have a nervous breakdown in the wake of Suez, the French over Algeria. They each represent 6-7\% of the Free World's power; and we could cover for them. But we can't afford 
a nervous breakdown. We're $40 \%$, and there's no one to cover for us. We'd better get on with the job.' And so we did.

But what is the job now? What policy should the Untted States pursue in a world in which much larger, technologically competent, state-of-the-art nations seem destined to emerge over, say, the next half century. Although quite typically, Professor Kennedy hedges his bets with various formulations, his central message is clear: pull back from over-commitment, adjust passively, and make a success of the kind of appeasement he believes Britain followed until Hitler unfortunately made it impossible.

I would respond: the United States should stick with a new version of the balance of power policy we have pursued with some success for more than two centuries. Instinctively we know that an old fashioned balance of power policy will not suffice in a world of nuclear weapons and multiple major powers. We should not forget the array of those who mattered on both sides of the Atlantic when, as it often is, the course history would take was 'a damned close run thing': for example, Marlborough and Washington; Wellington and Lincoln; the pilots in the Battle of Britain and at Midway. But the gross disproportion between the power to destroy and the frailty of humanity argues that the techniques of power balance should be directed to the avoidance, if possible, of the need for that particular kind of heroism.

A new version of a balance of power policy lies in the broad direction Western Europe took, at long last, in the wake of the Second World War, after five centuries and more of internecine blood-letting. In order to balance the power of Germany on the one hand, the United States and the Soviet Union on the other, Western Europe moved towards intensified, institutionalized coopera- 
tion and, perhaps, ultimately to unity. Great Britain could have and should have led that effort. For explicable but unfortunate reasons it did not. But the fact is that the European community represents a more civilized version of the balance of power policy Britain pursued for centuries at times of power crisis in Europe.

The answer for the United States at this historical interval, when its relative power and influence while diminished still transcends by far that of any other power, is, in a sense, to pursue on a wider basis the policy Britain should have pursued toward Europe after 1945; that is, to move forward with others to give institutional substance to the profound common interests that suffuse the Pacific Basin and tame forehandedly the tensions which exist or might emerge; to move similarly in a new spirit of authentic partnership within the Western Hemisphere; to tighten the ties of partnership within the Atlantic community; and to hold out to the Soviet Union a vision of a soft landing from the cold War and of a United Nations which might begin to fulfill the large hopes which accompanied its birth.

A United States, having recovered economic balance, industrious, as Hume counseled, prudently armed, committed to such a civilized policy and program in the face of $/$ diffusion of power also capable of yielding a bloody neo-mercantilist bearpit, would not lack colleagues and friends along the way.

In more immediate terms there is a case for adjusting carefully and maturely the economic burdens within the alliances across the Atlantic and Pacific in the light of recent shifts in relative economic and technological capacity. There is no 
case for radical change in the structure or purposes of those alliances, committed as they are to both defense and conciliation, arms and arms control. On the contrary, their steadiness and continuity are fundamental to the possibility of a successful transition from where we are to a liquidation , of the cold War. Another blind American retraction, as in 1945-46 and the 1970's, which Paul Kennedy's false analogies tend to encourage, could destroy that possibility. 